\title{
Sand fly and Leishmania spp. survey in Vojvodina (Serbia): first detection of Leishmania infantum DNA in sand flies and the first record of Phlebotomus
} (Transphlebotomus) mascittii Grassi, 1908

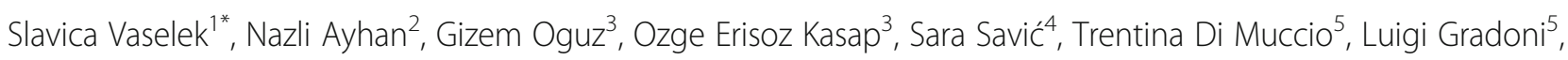
Yusuf Ozbel ${ }^{6}$, Bulent Alten ${ }^{3}$ and Dušan Petrić

\begin{abstract}
Background: Leishmaniasis in Serbia was an endemic disease, and is considered to be eradicated for more than 40 years. In the past decade sporadic cases of canine leishmaniasis started to emerge for the first time in Vojvodina Province (previously non-endemic region of Serbia). Reports of introduced, and later on autochthonous cases of leishmaniasis alerted the possibility of disease emergence. The aim of this study was to bridge more than a half a century wide gap in entomological surveillance of sand fly vectors in Vojvodina, as well as to verify the presence of the vector species that could support Leishmania spp. circulation.

Results: During the period 2013-2015, a total of 136 sand flies were collected from 48 of 80 surveyed locations. Four sand fly species of the genus Phlebotomus were detected: P. papatasi, P. perfiliewi, P. mascittii and P. neglectus. Detection of $P$. mascittii represents the first record of this species for the sand fly fauna in Vojvodina and in Serbia. All female specimens $(n=80)$ were tested for Leishmania spp. DNA, and three blood-fed P. papatasi specimens were positive (4\%). One positive DNA sample was successfully amplified by ITS1 nPCR. The RFLP analysis of the resulting $350 \mathrm{bp}$ fragment showed a typical pattern of L. infantum, and the ITS1 partial sequence blasted in GenBank confirmed $100 \%$ identity with L. infantum and L. donovani complex sequences. This result represents the first record of both Leishmania spp. and L. infantum DNA from sand flies in Vojvodina, and in Serbia.

Conclusions: Presence of autochthonous canine leishmaniasis cases, records of Phlebotomus (Larroussius) species proven vectors of $L$. infantum (P. perfiliewi and P. neglectus) and detection of $L$. infantum DNA from wild caught (non-competent) vectors, prove that $L$. infantum is present in Vojvodina and indicates a probable circulation in the region.
\end{abstract}

Keywords: Sand fly, Phlebotomus, Leishmaniasis, Leishmania infantum, Serbia

\footnotetext{
*Correspondence: slavica.vaselek@gmail.com

${ }^{1}$ Faculty of Agriculture, Department of Phytomedicine and Plant Protection, Laboratory for Medical Entomology, University of Novi Sad, Novi Sad, Serbia Full list of author information is available at the end of the article
} 


\section{Background}

The leishmaniases are major vector-borne diseases caused by protozoan parasites belonging to the genus Leishmania. The parasites are transmitted to humans and other vertebrates by the bite of infected female sand flies (Psychodidae, Phlebotominae). Around one billion of people are at risk of infection while number of reported cases per year is estimated at 0.7-1.3 million for cutaneous leishmaniasis (CL) and 200,000-400,000 for visceral leishmaniasis (VL), causing over than 20,000 deaths annually [1].

In Europe, leishmaniasis is endemic in all southern countries, with $\sim 700$ (3950 if Turkey is included) autochthonous human cases reported every year [1]. The spread of Leishmania infantum, causative agent of zoonotic VL and CL in humans and domestic dogs (reservoir host) represents a major threat to Europe. Increasing dog and human travel, as well as the ongoing migrant crisis, pose a significant risk of $L$. infantum introduction into central Europe. Climate and land cover changes could also support northward dispersal of vectors, establishment of seasonal biting rates matching those of southern Europe, hence permitting autochthonous transmission [2].

In Serbia, leishmaniasis started to emerge after the Second World War. Due to the composition and abundance of sand fly species at that time, poor hygienic and health conditions in the post-war period, the disease rapidly assumed an epidemic character [3]. The first autochthonous case of VL was reported in 1945 [4]. From 1945 to 1955, leishmaniasis spread in epidemic waves from the southern parts of the country northwards, reaching its northernmost limit in central Serbia. After the last major epidemic (1953), the number of new cases started to diminish and, in the following years, the disease appeared only sporadically. The last case of VL was reported in 1968 [5], thereafter the disease was considered eradicated.

Sand fly research in Serbia was initiated in 1947, soon after first cases of autochthonous VL emerged, and was terminated in 1990. During this period, the presence of seven species of the genus Phlebotomus was recorded: Phlebotomus papatasi, P. perfiliewi, P. tobbi, P. neglectus, $P$. simici, P. sergenti and P. balcanicus [6]. The most intensive sand fly investigations were conducted during the VL epidemics, mainly in the infested areas. Following the disease spread, sand fly research was mainly focused on the south-east, east and central Serbia, leaving all other areas of country unexplored or partially explored. One of these less investigated and leishmaniasis-free region of Serbia includes Vojvodina Province, located in the north of the country.

Vojvodina was surveyed only briefly between 1949 and 1951. Research was conducted irregularly (through the years and seasons) and only in a small number of locations. Studies revealed the presence of only three species:
P. papatasi, $P$. perfiliewi and P. neglectus [7]. The number of specimens caught was rather low, with several samples collected from various villages or from various houses in the same village. Low sand fly diversity and abundance, as well as the absence of human cases, resulted in the neglect of sand fly studies in this area for more than 60 years.

In the past decade, since 2006, cases of canine leishmaniasis have started to emerge for the first time in Vojvodina. Clinical symptoms and positive serological findings were first diagnosed in dogs that were imported or had travelled abroad to some of the Mediterranean countries with endemic leishmaniasis [8]. Subsequent findings (2010-2013) involved dogs that had never travelled from their home in Vojvodina [9]. This information suggested that both parasite and vector species are present in the region and implicated the possibility of autochthonous transmission.

The aim of this study was to bridge more than a half a century wide gap in entomological surveillance of sand fly vectors in Vojvodina, a very important transition region of Europe, as well as to verify the presence of the vector species that could support Leishmania spp. circulation.

\section{Methods \\ Sand fly sampling}

Cross-sectional entomological surveys were conducted between 2013 and 2015 in selected sample sites of the Vojvodina Province (North Serbia). A total of 80 villages were surveyed: 17 in 2013, 24 in 2014 and 39 in 2015. Surveys were conducted from the middle of May until the middle of September. Due to the restricted funding, sites sampled positive at first collection were not resampled, whereas negative locations were sampled again. Sampling locations were partly chosen according to the available data about sand fly presence obtained during previous investigations (1948-1951) and data regarding reported and/or suspected cases of canine leishmaniasis (2006-2013). The remaining locations are situated in areas without any data of sand fly and/or leishmaniasis presence.

Multiple sampling techniques were used to increase the number of specimens sampled, as low abundance was expected according to historical data. Indoor and outdoor populations of sand flies were collected using a miniature Centre for Disease Control (CDC) light traps (John W. Hock Company, model 512, Gainesville, Florida, U.S.A.), dry-ice baited traps without light (NS2 type), dry-ice baited traps with light, sticky papers and mouth aspirators. Suction traps were operating overnight, set at 16:00 $\mathrm{h}$ and collected at 08:00 $\mathrm{h}$ the next day. Traps were placed $\sim 1.5 \mathrm{~m}$ above the ground inside (CDC) and outside (traps with dry ice) of the houses and animal shelters. Sticky traps $(20 \times 30 \mathrm{~cm}$ papers coated with commercial castor oil) were placed in holes surrounding walls of animal shelters and houses, and all 
other suitable sand fly resting places, for a period of four days. Indoor collections were performed during the daylight using mouth aspirators.

\section{Morphological identification of sand flies}

All specimens collected were immediately transferred to $96 \%$ ethanol. Specimens were dissected; head and terminal segments of the abdomen were removed, cleared in Marc Andre solution and mounted in Berlese medium. The head and the tip of the abdomen were used for morphological identification, while the rest of the body was transferred to a separate tube with $70 \%$ ethanol and stored for DNA analyses. Morphological identification was based on characters of male genitalia, female spermathecae and pharyngeal armature $[10,11]$.

\section{Molecular identification of sand flies}

In order to validate the morphological identification of sand fly specimens, sequence analysis of cytochrome $c$ oxidase subunit 1 (cox1) mtDNA region was performed. PCR amplification was performed using the LCOI490/HCO2198 primer pairs according to the procedure of Folmer et al. [12]. The amplification products were electrophoresed trough $2 \%$ agarose gel and visualised under UV light. PCR products were purified using a QIAquick PCR Purification Kit (Qiagen, Hilden, Germany) and directly sequenced in both directions, using the same primers used for DNA amplification. Next-generation sequencing (NGS) was performed with BioRobot EZ1-XL Advanced (Qiagen). Sequences obtained were edited and aligned using BioEdit (7.0.9.0) [13] and compared with those available in GenBank using Neighbor Joining algorithm under the assumption of Kimura's two parameter model in MEGA 6.06 [14].

\section{Detection of Leishmania spp.}

Presence of leishmanial DNA was assayed individually in all females [15]. Small-subunit (SSU) ribosomal DNA was amplified by a sensitive nested (n) PCR technique using the Kinetoplastida and Leishmania genus-specific primers in the first and second PCR round, respectively [16]. Negative (no DNA) and positive (DNA from cultured L. infantum promastigotes) controls were used in all experiments. PCR products were electrophoresed through 1.5\% agarose gel and visualized under UV light. Positive samples yielded a predicted nPCR product of 358 bp. Leishmania-positive DNA samples were then examined individually by internal transcribed spacer (ITS) $1 \mathrm{nPCR}$ using LITSR/L.5.8S primers, and the amplified fragment analyzed by both restriction fragment length polymorphism (RFLP) and sequencing analysis for Leishmania species identification [17].

\section{Results}

During 2013-2015, a total of 136 sand flies were collected from 48 of 80 locations (Fig. 1). Four sand fly species of the genus Phlebotomus were identified: P. papatasi, P. perfiliewi, $P$. mascittii and $P$. neglectus (Table 1). The majority of specimens $(n=130)$ belonged to P. papatasi ( $75 \mathrm{fe}-$ males, 54 males, 1 undetermined) (GenBank: KY848828), three females were identified as $P$. perfiliewi (GenBank: KY848829), two females as $P$. mascittii and one female as P. neglectus (GenBank: KY848830). Phlebotomus papatasi was the predominant species in Vojvodina, found in 55\% of surveyed locations (91.67\% of positive locations).

Presence of $P$. mascittii, a member of the Phlebotomus (Transphlebotomus) subgenus had not previously been reported from Vojvodina (or Serbia). During 2015, two female specimens of $P$. mascittii were collected in urban environment of Ležimir and Parage villages (geographical position given in Table 1). The first specimen was collected in Ležimir $(18 / 06 / 2015)$ in a $\mathrm{CDC} / \mathrm{CO}_{2}$ trap placed under a concrete roof that connects a brick storage shed and pig stain, creating a approximately $7 \mathrm{~m}$ tunnel like passage between the front (human) and back yard (animal dwelling). Mean monthly temperature for June in Ležimir were $18.6{ }^{\circ} \mathrm{C}$ at $07: 00 \mathrm{~h}, 25.9^{\circ} \mathrm{C}$ at $14: 00$ $\mathrm{h}$ and $19.1{ }^{\circ} \mathrm{C}$ at $21: 00 \mathrm{~h}$ (source: national network of synoptic stations, station at Sremska Mitrovica, $\sim 18 \mathrm{~km}$ from Ležimir). The second specimen was collected in Parage $01 / 08 / 2015$ with a $\mathrm{CO}_{2}$ trap placed next to the brick wall of the house approximately $50 \mathrm{~m}$ from animals. Mean monthly temperature for August in Parage were $20.5{ }^{\circ} \mathrm{C}$ at $07: 00 \mathrm{~h}, 30.6{ }^{\circ} \mathrm{C}$ at $14: 00 \mathrm{~h}$ and $23.4{ }^{\circ} \mathrm{C}$ at $21: 00 \mathrm{~h}$ (source: national network of synoptic stations, station at Rimski Šančevi, $\sim 35 \mathrm{~km}$ from Parage). Both specimens were identified morphologically, and specimen identification was confirmed by sequence analysis of the cox 1 mitochondrial gene region. Sequences obtained (GenBank: KY848831) were blasted against the database from GenBank and were identified as $P$. mascittii (Fig. 2). This report of $P$. mascitii represents the first record of this species in sand fly fauna of Vojvodina and in Serbia.

All female specimens $(n=80)$ were tested for Leishmania DNA; three blood-fed P. papatasi specimens were positive (4\%). All positive females were collected in 2013 (3/37) from different settlements (Golubinci, Inđija and Opovo), thus resulting in $8.1 \%$ infection prevalence in that year. Only one positive DNA sample was successfully amplified by ITS1 nPCR. The RFLP analysis of the resulting 358 bp fragment showed a typical pattern of L. infantum, and the ITS1 partial sequence (GenBank: KY646445) was compared to those in GenBank, which confirmed the identity as $L$. infantum and $L$. donovani complex sequences (100\% match). These results represent the first record of both Leishmania and L. infantum DNA from sand flies in Vojvodina and in Serbia. 


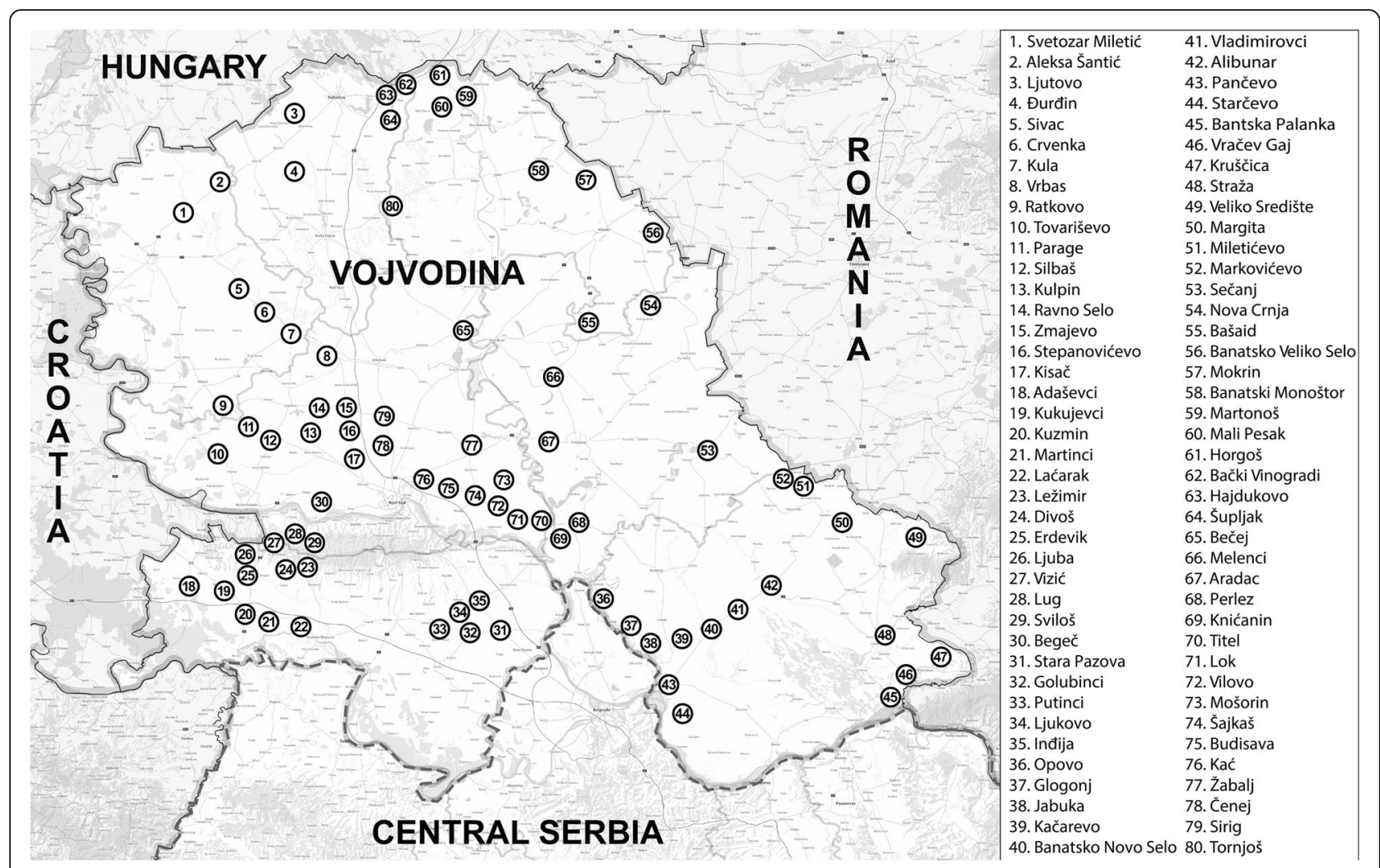

Fig. 1 Sand fly collection localities in the study area

Due to the low number of specimens sampled, we were not able to statistically compare different sampling techniques. However, most of the specimens were sampled by CDC $(n=80)$, then $\mathrm{CDC} / \mathrm{CO}_{2}(n=31)$ and the least by only $\mathrm{CO}_{2}(n=25)$. No sand flies were sampled by sticky traps and mouth aspirators.

\section{Discussion}

Sand fly research in Vojvodina was neglected for more than 60 years. Previous investigations conducted in the period 1949-1951 indicated a low diversity of sand flies, with only three species reported ( $P$. papatasi, $P$. perfiliewi and P. neglectus) [18]. According to the old data $P$. papatasi was predominant species, being found in the majority of investigated locations in low numbers (1-2 specimens from various locations of the same village), while P. neglectus [19] and P. perfiliewi [20] were present in both, a limited number of locations and in the number of individuals (1-2 specimens from various villages).

Our results coincide partially with these data, confirming the presence of three previously reported species and indicating that, even in low numbers, $P$. papatasi remained the predominant species in Vojvodina, being found in $55 \%$ of all surveyed locations $(91.67 \%$ of positive locations) (Table 1). Low densities of $P$. perfiliewi and $P$. neglectus were also confirmed; three specimens of
P. perfiliewi were found ( 1 in 2013, 2 in 2015) and just one specimen of $P$. neglectus (2015).

The two specimens of $P$. mascittii represent first record for Vojvodina and the whole of Serbia, and may indicate a change in the composition of sand fly fauna in the region. Phlebotomus mascittii is a species found in Mediterranean region [21], as well as in countries with colder climate like Austria [22], Belgium [23] and Germany [24] with a northernmost border in Slovakia [25]. Considering its usually low abundance [26], and fact that species is present in countries bordering with our research area (e.g. Croatia [27] and Hungary [28]), there is a possibility that $P$. mascittii was already present in Serbia for several years, but remained undetected before 2015.

Patchy distribution and low density of sand flies is more prominent in Vojvodina than in other parts of Serbia, since Vojvodina is predominantly an agricultural region with a heavy use of insecticides. Large cultivated fields greatly influence sand fly dispersal potential and limit their distribution to small isolated clusters. Favourable weather condition, suitable topography and plentiful of food sources enable sand flies to maintain small, but steady, populations. Our data show that fragmented populations of sand flies are present across all of Vojvodina (Fig. 1). 
Table 1 Positive sand fly localities (coordinates, trapping dates, trap type, number of samples, species and gender)

\begin{tabular}{|c|c|c|c|c|c|c|c|c|}
\hline \multirow[t]{2}{*}{ Locality } & \multirow[t]{2}{*}{ Latitude } & \multirow[t]{2}{*}{ Longitude } & \multirow{2}{*}{$\begin{array}{l}\text { No. of } \\
\text { specimens }\end{array}$} & \multirow[t]{2}{*}{ Date } & \multirow{2}{*}{$\begin{array}{l}\text { Species and gender } \\
\text { (male/female) }\end{array}$} & \multicolumn{3}{|c|}{ Positive trap type } \\
\hline & & & & & & $\overline{C D C}$ & $\mathrm{CDC} / \mathrm{CO}_{2}$ & $\mathrm{CO}_{2}$ \\
\hline \multirow[t]{2}{*}{ Opovo $^{a}$} & 45.0501220 & 20.4341260 & 8 & $21 / 07 / 2013$ & P. papatasi (1 m/5f) & $x$ & - & - \\
\hline & & & & $11 / 06 / 2014$ & P. papatasi (1 m/1f) & $x$ & - & - \\
\hline Inđija & 45.0353556 & 20.0790806 & 7 & $24 / 08 / 2013$ & P. papatasi (2 m/5f) & $\times$ & - & - \\
\hline Golubinci & 44.9836306 & 20.0715722 & 3 & $24 / 08 / 2013$ & P. papatasi (2 m/1f) & $\times$ & - & - \\
\hline Putinci & 44.9952167 & 19.9623000 & 10 & $24 / 08 / 2013$ & P. papatasi (2 m/8f) & $\times$ & - & - \\
\hline Ljukovo & 45.0295639 & 20.0227056 & 1 & $24 / 08 / 2013$ & P. papatasi (1 m) & $\times$ & - & - \\
\hline Vladimirovci & 45.0322167 & 20.8762667 & 20 & $21 / 07 / 2013$ & P. papatasi $(7 \mathrm{~m} / 13 \mathrm{f})$ & $\times$ & - & - \\
\hline Kačarevo & 44.9623333 & 20.7128667 & 1 & $21 / 07 / 2013$ & P. perfiliewi (1f) & $x$ & - & - \\
\hline \multirow[t]{2}{*}{ Bečej } & 45.6151970 & 20.0268460 & 2 & $24 / 07 / 2013$ & P. papatasi (1f) & - & - & $x$ \\
\hline & & & & $23 / 08 / 2015$ & P. papatasi (1 m) & - & - & $\times$ \\
\hline \multirow[t]{3}{*}{ Kać } & 45.3033710 & 19.9292900 & 4 & $25 / 07 / 2013$ & P. papatasi (1f) & $\times$ & - & - \\
\hline & & & & 29/07/2013 & P. papatasi (1 m) & $x$ & - & - \\
\hline & & & & $30 / 07 / 2013$ & P. papatasi (1 m/1f) & $x$ & - & - \\
\hline Begeča $^{2}$ & 45.2380420 & 19.6228380 & 1 & $31 / 07 / 2013$ & P. papatasi (1 m) & $\times$ & - & - \\
\hline Čenej & 45.3692500 & 19.8042833 & 1 & $31 / 07 / 2013$ & P. papatasi (1f) & $\times$ & - & - \\
\hline Stara Pazova & 44.9839278 & 20.1797111 & 2 & $02 / 09 / 2015$ & P. papatasi $(1 \mathrm{~m} / 1 \mathrm{f})$ & - & - & $\times$ \\
\hline Budisava & 45.2803167 & 19.9990833 & 1 & $22 / 07 / 2014$ & P. papatasi (1f) & $\times$ & - & - \\
\hline \multirow[t]{2}{*}{ Šajkaš } & 45.2664833 & 20.0925833 & 5 & $17 / 07 / 2014$ & P. papatasi (1 m/2f) & $\times$ & - & - \\
\hline & & & & $22 / 07 / 2014$ & P. papatasi (2 m) & $x$ & - & - \\
\hline \multirow[t]{2}{*}{ Žabalj } & 45.3755500 & 20.0761333 & 5 & $17 / 07 / 2014$ & P. papatasi (1 m/1f) & $\times(1 f)$ & - & $\times(1 \mathrm{~m})$ \\
\hline & & & & $22 / 07 / 2014$ & P. papatasi (3 m) & $\times(2 \mathrm{~m})$ & - & $\times(1 \mathrm{~m})$ \\
\hline Mošorin & 45.2967333 & 20.1547333 & 2 & $26 / 07 / 2014$ & P. papatasi (1 m/1f) & - & - & $x$ \\
\hline Vilovo & 45.2483500 & 20.1535500 & 1 & $26 / 07 / 2014$ & P. papatasi (1 m) & $\times$ & - & - \\
\hline Perlez & 45.2098500 & 20.3902333 & 2 & $26 / 07 / 2014$ & P. papatasi (2f) & $\times$ & - & - \\
\hline Knićanin & 45.1883167 & 20.3164167 & 2 & $26 / 07 / 2014$ & P. papatasi (1 m/1f) & $\times$ & - & - \\
\hline Ljuba & 45.1568333 & 19.3911167 & 1 & $19 / 08 / 2014$ & P. papatasi (1f) & $\times$ & - & - \\
\hline Kuzmin & 45.3040833 & 19.9285889 & 1 & $30 / 07 / 2014$ & P. papatasi (1f) & - & - & $x$ \\
\hline Vrbas & 45.5809000 & 19.6322000 & 1 & $14 / 08 / 2014$ & P. papatasi (1f) & $\times$ & - & - \\
\hline Kula & 45.6178500 & 19.5127333 & 1 & $14 / 08 / 2014$ & P. papatasi (1f) & $\times$ & - & - \\
\hline Lok & 45.2183000 & 20.2113333 & 4 & $26 / 07 / 2014$ & P. papatasi (4f) & $x$ & - & - \\
\hline Lug & 45.1876667 & 19.5429667 & 1 & $21 / 07 / 2015$ & P. papatasi (1 m) & - & - & $x$ \\
\hline \multirow[t]{2}{*}{ Divoš } & 45.1115167 & 19.5095333 & 5 & 02/09/2015 & P. papatasi (2f) & - & $\times$ & $x$ \\
\hline & & & & $21 / 07 / 2015$ & P. papatasi (2 m/1f) & - & $\times$ & - \\
\hline Martinci & 45.0132167 & 19.4452000 & 1 & 02/09/2015 & P. papatasi (1 m) & - & $\times$ & - \\
\hline \multirow[t]{3}{*}{ Ležimir } & 45.1138333 & 19.5672500 & 3 & $02 / 09 / 2015$ & P. papatasi (1 m) & - & $\times$ & - \\
\hline & & & & $18 / 06 / 2015$ & P. mascittii (1f) & - & $\times$ & - \\
\hline & & & & $21 / 07 / 2015$ & P. papatasi (1f) & - & - & $\times$ \\
\hline \multirow[t]{2}{*}{ Bašaid } & 45.6356500 & 20.4080500 & 2 & $01 / 06 / 2015$ & P. papatasi (1 m) & - & $\times$ & - \\
\hline & & & & $16 / 07 / 2015$ & P. papatasi (1f) & $\times$ & - & - \\
\hline Nova Crnja & 45.6698167 & 20.6086833 & 2 & $14 / 06 / 2015$ & P. papatasi (1 m/1f) & - & - & $\times$ \\
\hline Banatsko Veliko Selo & 45.8157167 & 20.6091500 & 1 & $16 / 07 / 2015$ & P. papatasi (1f) & - & $\times$ & - \\
\hline Banatski Monoštor & 45.9633000 & 20.2824167 & 1 & $16 / 07 / 2015$ & P. perfiliewi (1f) & - & $\times$ & - \\
\hline Svetozar Miletić & 45.8497833 & 19.1965667 & 1 & 20/08/2015 & P. neglectus (1f) & - & $\times$ & - \\
\hline Aradac & 45.3768667 & 20.3025833 & 1 & 03/06/2015 & P. papatasi (1 m) & - & - & $\times$ \\
\hline
\end{tabular}


Table 1 Positive sand fly localities (coordinates, trapping dates, trap type, number of samples, species and gender) (Continued)

\begin{tabular}{|c|c|c|c|c|c|c|c|c|}
\hline \multirow[t]{2}{*}{ Locality } & \multirow[t]{2}{*}{ Latitude } & \multirow[t]{2}{*}{ Longitude } & \multirow{2}{*}{$\begin{array}{l}\text { No. of } \\
\text { specimens }\end{array}$} & \multirow[t]{2}{*}{ Date } & \multirow{2}{*}{$\begin{array}{l}\text { Species and gender } \\
\text { (male/female) }\end{array}$} & \multicolumn{3}{|c|}{ Positive trap type } \\
\hline & & & & & & CDC & $\mathrm{CDC} / \mathrm{CO}_{2}$ & $\mathrm{CO}_{2}$ \\
\hline Markovićevo & 45.3249833 & 21.0331667 & 1 & 05/09/2015 & P. papatasi (1f) & - & $\times$ & - \\
\hline Miletićevo & 45.3037167 & 21.0601500 & 1 & $22 / 08 / 2015$ & P. papatasi (1f) & - & - & $x$ \\
\hline Straža & 44.9722500 & 21.3015000 & 1 & $16 / 06 / 2015$ & P. papatasi (1 m) & - & - & $x$ \\
\hline \multirow[t]{2}{*}{ Vračev Gaj } & 44.8822000 & 21.3702167 & 2 & 22/08/2015 & P. papatasi (1na) & - & $\times$ & - \\
\hline & & & & 05/09/2015 & P. papatasi (1 m) & - & $x$ & - \\
\hline Banatska Palanka & 44.8463833 & 21.3344667 & 2 & $14 / 07 / 2015$ & P. papatasi (2 m) & - & - & $\times$ \\
\hline Melenci & 45.5282972 & 20.3037944 & 1 & 29/07/2015 & P. perfiliewi (1f) & - & - & $x$ \\
\hline \multirow[t]{2}{*}{ Parage } & 45.4154278 & 19.4045500 & 2 & $16 / 08 / 2015$ & P. papatasi (1f) & - & - & $x$ \\
\hline & & & & $01 / 08 / 2015$ & P. mascittii (1f) & - & - & $\times$ \\
\hline Starčevo & 45.4045000 & 19.7076333 & 1 & 28/06/2015 & P. papatasi (1f) & - & - & $x$ \\
\hline Ravno selo & 45.4525200 & 19.6197600 & 8 & $20 / 07 / 2015$ & P. papatasi $(6 \mathrm{~m} / 2 \mathrm{f})$ & - & $\times$ & - \\
\hline Ratkovo & 45.4482900 & 19.3300200 & 3 & $19 / 07 / 2015$ & P. papatasi (3f) & - & $\times(1 f)$ & $\times(2 f)$ \\
\hline Silbaš & 45.3800600 & 19.5037600 & 1 & $19 / 07 / 2015$ & P. papatasi (1f) & $x$ & - & - \\
\hline Kulpin & 45.3970900 & 19.5907200 & 2 & 20/07/2015 & P. papatasi (2 m) & $\times$ & $\times$ & - \\
\hline Zmajevo & 45.4445400 & 19.6998900 & 1 & 20/07/2015 & P. papatasi (1 m) & - & $\times$ & - \\
\hline Tovariševo & 45.3557600 & 19.3191400 & 6 & 19/07/2015 & P. papatasi (2 m/4f) & - & $\times$ & - \\
\hline Total: 48 & & & Total: 136 & & & 80 & 31 & 25 \\
\hline
\end{tabular}

Abbreviations: $f$ female, $m$ male, $n a$ unknown gender

aLocalities where Leishmania spp. presence in sand flies was recorded

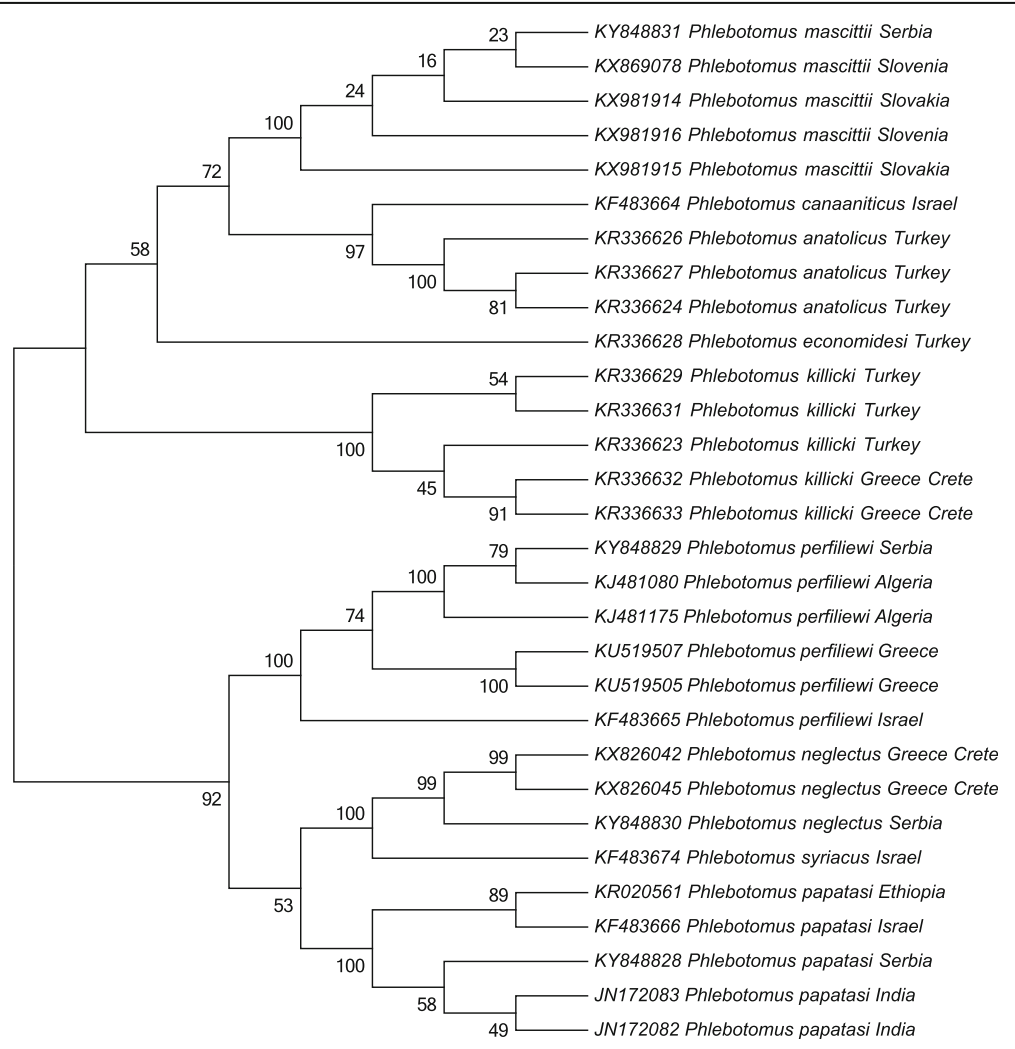

Fig. 2 Sequence analysis based on the cox 1 mitochondrial gene region in Phlebotomus species. Neighbor-joining tree based on the partial cox 1 sequences used for molecular identification of the sand fly specimens 
Considering the increased number of canine leishmaniasis in Vojvodina in the past decade, and the presence of phlebotomine species competent vectors of $L$. infantum, all collected females were tested for the presence of Leishmania. Of 80 samples examined, three $P$. papatasi specimens resulted positive (4\%) for Leishmania genus by nPCR. All positive females were collected in 2013 . Negative results in 2014 and 2015 might be consequence of low number of samples (per locality and year), and low abundance of the vector species in general.

Although P. papatasi is a highly specific vector of $L$. major [29], presence of $L$. infantum DNA in P. papatasi has been previously reported [30]. Detection of leishmanial DNA does not imply that the sand fly species is a vector, as the assay cannot distinguish among developmental phases of promastigotes in the gut of infected specimens. According to Adler \& Theodor [31], P. papatasi became infected after feeding on dogs with canine leishmaniasis, but the infection rate in the insects diminished continuously from $96 \%$ after one day, to $4 \%$ after 7 days (i.e. when the blood was digested). Our finding is most likely the direct result of recent blood-feeding, since all positive females had an abdomen full of blood, most likely engorged during the previous night(s).

Even though L. infantum DNA was detected from a non-competent vector, the fact that the parasite was identified from wild specimens, and the record of Phlebotomus (Larroussius) species proven vectors of $L$. infantum ( $P$. perfiliewi and $P$. neglectus) [32,33], indicates the possibility of $L$. infantum circulation in the surveyed region.

We wish also to highlight the importance of the $P$. mascittii record, since this species has long been suspected as a vector of $L$. infantum [34]. So far, P. mascittii has only been assumed to be a putative vector of Leishmania spp., however the recent detection of L. infantum DNA in specimens of P. mascittii from Austria [22] and Italy [21] may support possible competence in transmission (with the limitations exposed above about molecular assays for vector incrimination).

Despite the relatively low number of collected specimens, implication of leishmaniasis circulation in Vojvodina, and Serbia as a whole, seems to be accumulating. New cases of human autochthonous VL were recently registered in both past-endemic [35] and non-endemic areas of south-east Serbia [36]. Along with human and canine leishmaniasis cases, the presence of Leishmania spp. was also detected in the spleen of golden jackals (Mammalia, Canidae, Canis aureus) in central and east Serbia [37]. The possibility of vertical transmission among canine populations was discussed by Boggiatto et al. [38], and it is not excluded as a probable way of sustaining infection within wild and domestic canid population in Vojvodina/Serbia, since low numbers of sand flies were recorded. Beyond Serbia, reports of the disease are accumulating from all neighbouring countries [39-41]. Constant flow of humans, animals and commodities trough Vojvodina increases the risk of parasite introduction and disease emergence, since this region is situated in the main transit route of tourism and trade between the Mediterranean and Middle-eastern countries and Central and northern Europe.

\section{Conclusions}

Presence of autochthonous canine leishmaniasis cases, detection of L. infantum DNA from wild-caught (noncompetent) vector, and the record of Phlebotomus (Larroussius) species, which are proven vectors of $L$. infantum ( $P$. perfiliewi and $P$. neglectus), indicate the possible dynamics of endemic circulation of $L$. infantum in the surveyed region.

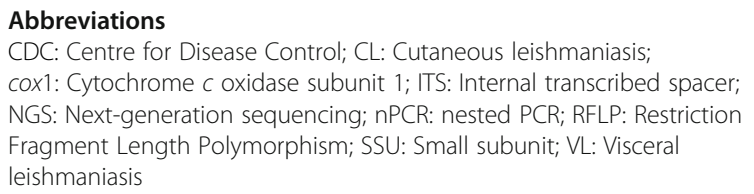

The work of Slavica Vaselek, Sara Savić, Yusuf Ozbel, Bulen Alten and Dušan Petrić was done under the frame of EurNegVec COST Action TD1303.

\section{Funding}

The work was carried out under the VectorNet project, a European network for sharing data on the geographic distribution of arthropod vectors, transmitting human and animal disease agents (Contract OC/EFSA/AHAW/ 2013/02-FWC 1) funded by the European Food Safety Authority (EFSA) and the European Centre for Disease Prevention and Control (ECDC); TR31084 project for Wild animal health monitoring and introduction of new biotechnology procedures in detection of infectious and zoonotic agents risk analysis for human health, domestic and wild animal health and for environmental contamination funded by the Ministry of Science, Education and Technical development of Republic of Serbia; and 13981-1 project for Diversity and spatial distribution of sandflies and pathogens they transmit (Leismania, phleboviruses) in Vojvodina province (Serbia) funded by the Rufford Small Grant Foundation.

\section{Availability of data and materials}

The datasets supporting the conclusions of this article are included within the article. The sequences have been deposited in the GenBank database under the accession numbers: KY848828 (Phlebotomus papatasi); KY848829 (Phlebotomus perfiliewi); KY848830 (Phlebotomus neglectus); KY848831

(Phlebotomus mascittii); and KY646445 (Leishmania).

\section{Authors' contributions \\ SV conducted the research planning, field sampling, morphological identification, molecular identification (extraction, PCR, sequencing), Leishmania spp. testing, wrote the original manuscript; NA conducted the field sampling, molecular identification of samples (extraction, PCR, sequencing); OEK completed molecular identification of samples (extraction, PCR, sequencing); GO participated in field sampling; SS and YO was involved in Leishmania spp. testing; TDM and LG were involved in Leishmania spp. testing, and Leishmania spp. sequencing; BA and DP were involved in research planning. All authors read and approved the final manuscript.}

Ethics approval and consent to participate Not applicable.

Consent for publication

Not applicable. 


\section{Competing interests}

The authors declare that they have no competing interests.

\section{Publisher's Note}

Springer Nature remains neutral with regard to jurisdictional claims in published maps and institutional affiliations.

\section{Author details}

'Faculty of Agriculture, Department of Phytomedicine and Plant Protection, Laboratory for Medical Entomology, University of Novi Sad, Novi Sad, Serbia. 2UMR "Emergence des Pathologies Virales" (EPV: Aix-Marseille Univ - IRD 190 - Inserm 1207 - EHESP - IHU Mediterranee infection), Marseille, France. ${ }^{3}$ Faculty of Science, Department of Biology, Ecology Division, VERG Laboratory, Hacettepe University, Beytepe, Ankara, Turkey. ${ }^{4}$ Scientific Veterinary Institute "Novi Sad", Novi Sad, Serbia. ${ }^{5}$ Department of Infectious Diseases, Istituto Superiore di Sanità, Rome, Italy. ${ }^{6}$ Faculty of Medicine, Ege University, Izmir, Turkey.

Received: 4 April 2017 Accepted: 17 September 2017 Published online: 26 September 2017

\section{References}

1. Dujardin JC, Campino L, Cañavate C, Dedet JP, Gradoni L, Soteriadou K et al. Spread of vector-borne diseases and neglect of leishmaniasis, Europe. Emerg Infect Diseases. 2008:14:1013-8.

2. Ready PD. Leishmaniasis emergence in Europe. Euro Surveill. 2010;15:19505.

3. Milovanović M, Popović D. Contribution to the study of kala-azar epidemic in PR Serbia. Glas Belgr Hig Inst NR Srb. 1960;9:23-7.

4. Saulic SP. Kala-azar in Macedonia and Serbia. Epidemiologic and geographic aspect. Hig Cas Hig Mikrobiol Epidemiol Sanit Teh. 1949;1:304-14.

5. Miščević Z, Milutinović M, Ivović V. Fauna and distribution of sandflies (Diptera, Phlebotomidae) in Yugoslavia, Croatia, Macedonia and their role in the transmission of parasitic and viral diseases. Acta Vet. 1998;48:163-72.

6. Živković V. Flebotomine (Diptera, Psychodidae) jugoistočne i istočne Srbije. Glas Srp Akad Nauk CCLXXI, Odeljenje Med Nauk. 1967;20:179-88.

7. Živkovic V. Faunistic and ecological investigations of sandflies (Diptera, Phlebotomidae) in Serbia. Phlebotomus papatasi (Scopoli, 1786) and Phlebotomus sergenti (Parrot, 1917). Acta Vet Brno. 1980;30:67-8.

8. Savić-Jevđenić S, Grgić Z, Vidić B, Vujkov B. Canine leishmaniosis - a clinical case. In: IX regional meeting in clinical pathology and therapy in animals Palic. Belgrade: Faculty of Veterinary Medicine; 2007. p. 2.

9. Savić S, Vidić B, Grgić Z, Bongiorno G, Gradoni L. Serological and clinical evidence of Leishmaniosis in a dog population living in a farm in northern Serbia. In: International SCIVAC congress - Canine Leishmaniosis and other vector-borne diseases: our current state of knowledge. March $8^{\text {th }}-10^{\text {th }}, 2013$, Italy. p. 120-2.

10. Lewis DJ. A taxonomic review of the genus Phlebotomus. Bull Br Mus Nat Hist. 1982;45:120-66.

11. Killick-Kendrick R, Tang Y, Killick-Kendrick M, Sang DK, Sirdar MK, Ke L, et al. The identification of female sandflies of the subgenus Larroussius by the morphology of the spermathecal ducts. Parassitologia. 1991;33:335-47.

12. Folmer $\mathrm{O}$, Black $M$, Hoeh W, Lutz R, Vrijenhoek R. DNA primers for amplification of mitochondrial cytochrome c oxidase subunit I from diverse metazoan invertebrates. Mol Mar Biol Biotechnol. 1994:3:294-9.

13. Hall T. BioEdit: a user-friendly biological sequence alignment editor and analysis program for windows 95/98/NT. Nucl Acids Symp Ser. 1999;41:95-8.14

14. Tamura K, Stecher G, Peterson D, Filipski A, Kumar S. MEGA6: Molecular Evolutionary Genetics Analysis version 6.0. Mol Biol Evol. 2013:30:2725-9.

15. Velo E, Paparisto A, Bongiorno G, Di Muccio T, Khoury C, Bino S, et al. Entomological and parasitological study on phlebotomine sandflies in central and northern Albania. Parasite. 2005;12:45-9.

16. van Eys GJ, Schoone GJ, Kroon NC, Ebeling SB. Sequence analysis of small subunit ribosomal RNA genes and its use for detection and identification of Leishmania parasites. Mol Biochem Parasitol. 1992;51:133-42.

17. Schönian G, Nasereddin A, Dinse N, Schweynoch C, Schallig HDFH, Presber W, et al. PCR diagnosis and characterization of Leishmania in local and imported clinical samples. DiagMicrobiol Infect Dis. 2003:47:349-58.

18. Simić Č, Kostić D, Nežić E, Živković V. Prilog poznavanju flebolomina Jugoslavije. VI deo - Flebotomine Vojvodine, Bosne, Hercegovine, Severne Dalmacije i Istre. Glas Srp Akad Nauk CCII - Odeljenje Med Nauk. 1951;3:81-6.
19. Živković V. Faunistic and ecological investigation of sandflies (Diptera, Phlebotomidae) in Serbia - P. major Annandale, 1910. Acta Vet Brno. 1982; 32:295-306.

20. Živkovic V. Faunistic and ecological investigation of sandflies (Diptera, Phlebotomidae) in Serbia - P. perfiliewi Parrot, 1930. Acta Vet Brno. 1983;33: 123-34.

21. Zanet S, Sposimo P, Trisciuoglio A, Giannini F, Strumia F, Ferroglio E. Epidemiology of Leishmania infantum, Toxoplasma gondii, and Neospora caninum in Rattus rattus in absence of domestic reservoir and definitive hosts. Vet Parasitol. 2014;199:247-9.

22. Obwaller AG, Karakus M, Poeppl W, Töz S, Özbel Y, Aspöck H, et al. Could Phlebotomus mascittii play a role as a natural vector for Leishmania infantum? New data. Parasit Vectors. 2016;9:458.

23. Depaquit J, Naucke TJ, Schmitt C, Ferté H, Léger N. A molecular analysis of the subgenus Transphlebotomus Artemiev, 1984 (Phlebotomus, Diptera, Psychodidae) inferred from ND4 mtDNA with new northern records of Phlebotomus mascittii Grassi, 1908. Parasitol Res. 2005;95:113-6.

24. Naucke TJ, Menn B, Massberg D, Lorentz S. Sandflies and leishmaniasis in Germany. Parasitol Res. 2008;103(Supp. 1):S65-8.

25. Dvorak V, Hlavackova K, Kocisova A, Volf P. First record of Phlebotomus (Transphlebotomus) mascittii in Slovakia. Parasite. 2016;23:48.

26. Maroli M, Bettini S. Leishmaniasis in Tuscany (Italy): (i) an investigation on phlebotomine sand flies in Grosseto Province. Trans R Soc Trop Med Hyg. 1977;71:315-21.

27. Bosnić S, Gradoni L, Khoury C, Maroli M. A review of leishmaniasis in Dalmatia (Croatia) and results from recent surveys on phlebotomine sandflies in three southern counties. Acta Trop. 2006;99:42-9.

28. Farkas R, Tánczos B, Bongiorno G, Maroli M, Dereure J, Ready PD. First surveys to investigate the presence of canine leishmaniasis and its phlebotomine vectors in Hungary. Vector Borne Zoonotic Dis. 2011;11:823-34.

29. Dostálová A, Volf P. Leishmania development in sand flies: parasite-vector interactions overview. Parasit Vectors. 2012;5:276.

30. Aransay AM, Scoulica E, Tselentis Y. Detection and identification of Leishmania DNA within naturally infected sand flies by seminested PCR on minicircle kinetoplastic DNA. Appl Environ Microbiol. 2000;66:1933-8.

31. Adler S, Theodor O. Investigation on Mediterranean Kala Azar. VI- canine visceral leishmaniasis. Proc R Soc Lond B Biol Sci. 1932;110:402-12.

32. Maroli M, Gramiccia M, Gradoni L. Natural infection of Phlebotomus perfiliewi with Leishmania infantum in a cutaneous leishmaniasis focus of the Abruzzi region, Italy. Trans R Soc Trop Med Hyg. 1987;81:596-8.

33. Léger N, Gramiccia M, Gradoni L, Madulo-Leblond G, Pesson B, Ferté H, et al. Isolation and typing of Leishmania infantum from Phlebotomus neglectus on the Island of Corfu, Greece. Trans R Soc Trop Med Hyg. 1988:82:419-20.

34. Pesson B, Leger N, Madulo-Leblond G, Petavy AF, Cambon M. La leishmaniose en Auvergne. Med Mal Infect. 1985;15:107-9.

35. Dakić ZD, Pelemis MR, Stevanović GD, Poluga JL, Lavadinović LS, Milošević IS, et al. Epidemiology and diagnostics of visceral leishmaniasis in Serbia. Clin Microbiol Infect. 2009;15:1173-6.

36. Dokmanović L, Krstovski N, Rodić $P$, Janić D. Visceral leishmaniasis associated hemophagocytic lymphohistiocytosis. Paediatr Today. 2012:8:65-9.

37. Cirović D, Chochlakis D, Tomanović S, Sukara R, Penezić A, Tselentis Y, et al. Presence of Leishmania and Brucella species in the golden jackal Canis aureus in Serbia. Biomed Res Int. 2014;728516

38. Boggiatto PM, Gibson-Corley KN, Metz K, Gallup JM, Hostetter JM, Mullin K et al. Transplacental transmission of Leishmania infantum as a means for continued disease incidence in North America. PLoS Negl Trop Dis. 2011;5:1-6.

39. Tatjana Z, Martinkovi F, Khoury C, Bongiorno G, Bosnić S, Luka D, et al. Serological and entomological studies of canine leishmaniosis in Croatia. Vet Arh. 2011:81:99-110.

40. Tánczos B, Balogh N, Király L, Biksi I, Szeredi L, Gyurkovsky M, et al. First record of autochthonous canine leishmaniasis in Hungary. Vector-Borne Zoonotic Dis. 2012;12:588-94.

41. Mircean V, Dumitrache MO, Mircean M, Bolfa P, Györke A, Mihalca AD Autochthonous canine leishmaniasis in Romania: neglected or (re)emerging? Parasit Vectors. 2014;7:135. 